\title{
Nitrogen budget in a microbial mat in the Camargue (southern France)
}

\author{
Patricia C. Bonin*, Valerie D. Michotey \\ Laboratoire de Microbiologie, de Géochimie et d'Ecologie Marine, CNRS-UMR 6117, Centre d'Océanologie de Marseille, \\ Campus de Luminy, Case 901, 13288 Marseille Cedex 9, France
}

\begin{abstract}
The main processes associated with the nitrogen cycle were studied in a microbial mat and in the surrounding water during winter (January), spring (March) and summer (June) in the Camargue (southeastern France). Denitrification, nitrogen fixation, nitrification, dissimilative reduction of nitrate, together with mineralization and ammonium assimilation, were measured under dark and light conditions using inhibitor and nitrogen isotope $\left({ }^{15} \mathrm{~N}\right)$. All these microbial processes were expressed in the mat. The isotope pairing method allowed the identification of the source of denitrified nitrate. It appeared that a major part of the nitrate formed by nitrification was denitrified and that nitrification was a considerable source of nitrate in spring and summer. From variations in net flux (fixation versus denitrification activities), we conclude that the mat acted as a nitrogen source in summer, but as a sink in winter.
\end{abstract}

KEY WORDS: Nitrogen cycle $\cdot$ Denitrification $\cdot$ Microbial mat

\section{INTRODUCTION}

Most microbial mats consist of laminated multi-colored layers resulting from stratified distribution of various photosynthetic (heterotrophic, chemotrophic and phototrophic) microorganisms that develop in the surface sediments as a consequence of vertical physicochemical gradients. Major biogeochemical cycles take place within this thin but complex layer. From a process perspective, di-nitrogen fixation, $\mathrm{CO}_{2}$ fixation, denitrification, nitrification, sulfate-reduction, methanogenesis, iron and other metal redox transformations may occur simultaneously within the mat (Paerl \& Pinckney 1996). Typically oxygenic photosynthetic microorganisms like diatoms and/or cyanobacteria develop at the surface of the mat. They function as primary producers and generate oxygen that can diffuse into the mat, leading to the establishment of strong oxygen gradients and fluctuating oxygenic/ anoxygenic interfaces. Deeper in the mat, the anoxic layer is characterized by a variety of chemolithotrophic, chemoorganotrophic and phototrophic microorganisms (Jørgensen \& Revsbech 1989).
Although a broad range of $\mathrm{N}$-transformations could occur, with nitrogen undergoing several redox reactions (states of oxidation ranging from -3 to +5 ), previous in situ studies of the nitrogen cycle in microbial mats strongly dominated by cyanobacteria have focused exclusively on the rates of $\mathrm{N}$-fixation (Paerl et al. 1993, 1996, Joye \& Paerl 1994, Paerl \& Pinckney 1996, Currin \& Paerl 1998). Denitrification is a key process in the nitrogen cycle, since it leads to a net nitrogen loss in the ecosystem by reducing nitrate to gaseous products and therefore helping control the rate of eutrophication in the environment. In contrast to denitrification, nitrate can also be reduced to ammonium by fermentative and strictly anaerobic bacteria, resulting in the preservation of nitrogen in its biologically available form (Bonin et al. 1998). It is now recognized that nitrification (oxidation of ammonium to nitrate) plays a pivotal role in generating a source of nitrate for denitrifying bacteria. In ecosystems with low nitrate levels $(<10 \mu \mathrm{M})$, nitrification (obligatory aerobic process) and denitrification (anaerobic process) are probably closely coupled. 


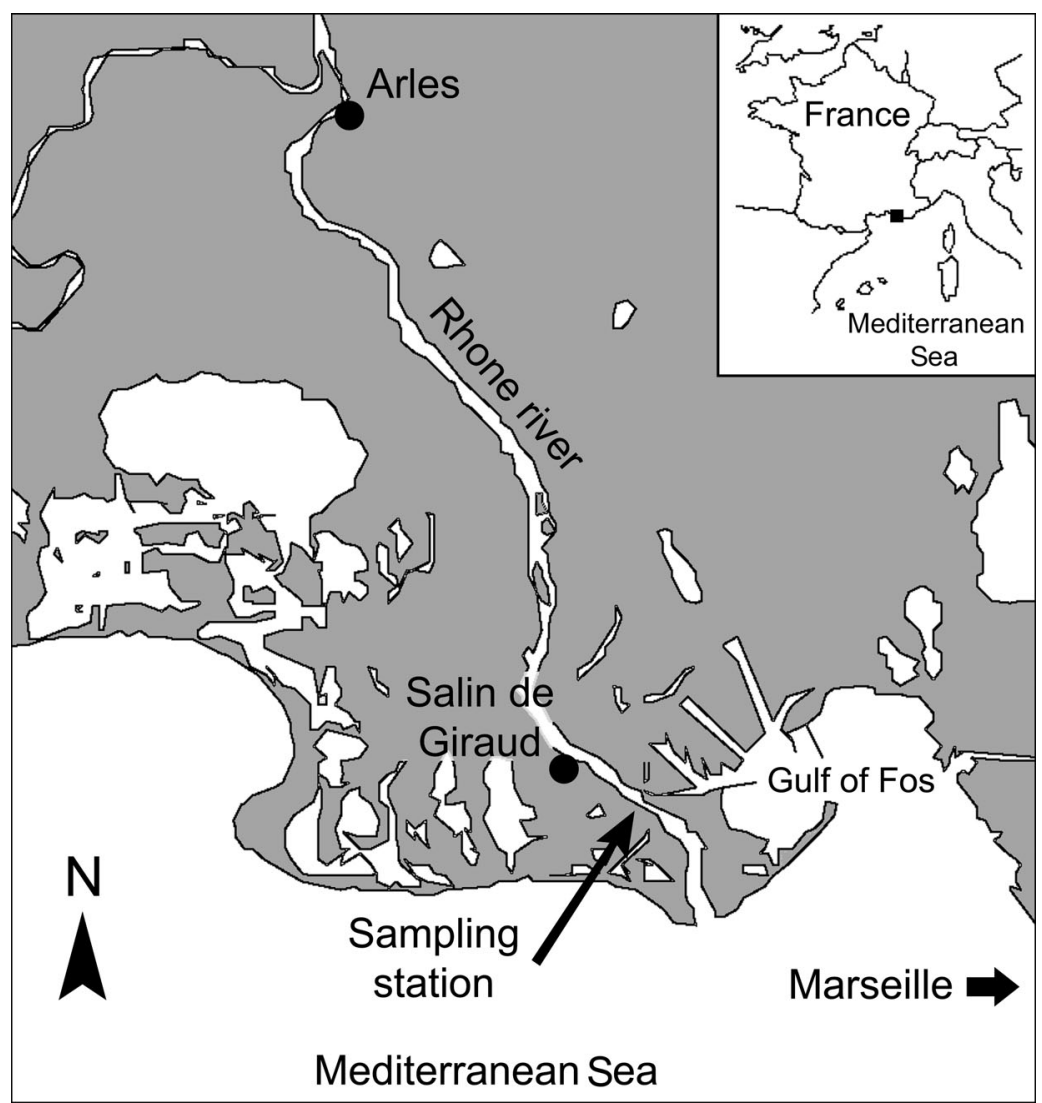

Fig. 1. Location of the sampling site

nitrogen cycle processes realized by micro-organisms, which present very diversified types of metabolism ranging from autotrophy to heterotrophy. However, from a biogeochemical perspective, nitrogen budgets in microbial mats cannot be fully understood without in situ quantification of nitrogen sources (N-fixation) and sinks (denitrification). However, whether mats act as sources or sinks for combined $\mathrm{N}$ depends, not only on the balance between $\mathrm{N}$-fixation and denitrification, but also on the rates of other processes producing (nitrification and mineralization, respectively) or consuming nitrate or ammonium (DNRA [dissimilative nitrate reduction to ammonium], nitrate or ammonium assimilation and anammox). Each of these transformations is reliant on an appropriate cellular and ambient microenvironmental or microzonal oxygen gradient and thus to specific redox conditions.

In the present study, nitrogen net fluxes were determined in a mat in the Camargue, using an isotopic technique, together with analyses of every individual process contributing to these fluxes (except anammox, which

The fact that few measurements of denitrification in cyanobacteria-dominated microbial mats have been published may be attributable to technical and interpretational difficulties, which are associated mainly with the commonly used method (acetylene block method; Bonin 1996). Acetylene not only inhibits the terminal step of denitrification but also affects other processes of the nitrogen cycle. Acetylene blocks nitrification, and this interruption in nitrate supply could result in the underestimation of denitrification (Hynes \& Knowles 1978, Walter et al. 1979, Hyman \& Wood 1985). Furthermore, acetylene can be converted to ethylene by nitrogen-fixing bacteria, leading to a suppression of the inhibition of the nitrous oxide reduction (Van Raalte \& Patriquin 1979). Knowledge of the nitrogen cycle in mats could be improved by the application of tracer techniques, especially those using stable isotope $\left({ }^{15} \mathrm{~N}\right)$. This isotopic technique circumvents the limitation of the acetylene block method and facilitates the determination of the reduction of nitrate originating either from downwards diffusion from the overlying water or from nitrification.

Our present level of understanding is not yet sufficient to establish an overview of the interactions of the seems negligible in this ecosystem). Inter-relations between each process were identified at different sampling times throughout the year (winter, spring and summer) under light and dark conditions.

\section{MATERIALS AND METHODS}

Characterization of the study area. The mat studied was located on the bottom of the saline pond used for the storage of water by the salterns of Salins-deGiraud (Camargue, southeastern France) (Fig. 1). The mat was dominated by cyanobacteria and covered a very large area ( 20 to $40 \mathrm{~km}^{2}$ ) (Caumette et al. 1994, Fourçans et al. 2004). It consisted of 3 distinct, colored and laminated layers, and was about 1 to $5 \mathrm{~cm}$ thick. An upper, approximately $2 \mathrm{~mm}$ thick, brown-green colored layer was composed of filamentous cyanobacteria, morphologically related to the genus Microcoleus, and of unicellular cyanobacteria, similar to the form genus Synechocystis, as well as of a few diatoms (Nitzschia sp.). Under this dense cyanobacterial layer, a $1 \mathrm{~mm}$ thick, purple layer was composed of purple non-sulfur bacteria, morphologically resembling mem- 
bers of the families Rhodospirillaceae and Chromatiaceae. Beneath these 2 layers a black zone of $>1 \mathrm{~cm}$ occurred with iron-sulfide precipitates, indicating the presence of sulfate-reducing bacteria (Desulfovibrio sp. and Desulfobacter sp.). Biomarker, microscopic and molecular analysis of this mat also revealed the presence of different populations of photosynthetic anoxygenic bacteria (e.g. Halochromatium salexigens, Roseospira marina, Rhodobacter sp., Ectothiorhodospira sp.) and green non-sulfur bacteria (green Chloroflexus-like bacteria). The detailed microbial composition and depth zonation of major bacterial groups in this mat have been published elsewhere (Fourçans et al. 2004). This mat was permanently submerged, and the overlying water depth never exceeded $20 \mathrm{~cm}$. Squares from this mat were collected in March and June 2000 and in January and June 2001. The salinities of the water column were 105 and 130 in March and June 2000, respectively, and 95 and 120 in January and June 2001, respectively. The water temperatures were $21.8,20,17$ and $20.8^{\circ} \mathrm{C}$ in March and June 2000 and in January and June 2001, respectively. Due to the shallow depth of the water column and to strong sunlight exposure, daily variation in water temperature may be large $\left( \pm 10^{\circ} \mathrm{C}\right)$. Surface irradiance around noon on clear and sunny days in summer was $\sim 1300 \mu \mathrm{mol}$ photons $\mathrm{m}^{-2} \mathrm{~s}^{-1}$. The concentration of dissolved oxygen in the overlying water was $\sim 20 \mathrm{ppm}$. The redox level at the surface of the mat ranged from -34 to $0 \mathrm{mV}$ (Wieland et al. 2005).

Sampling. Samples were always removed by hand around midday. Using a spatula, squares of mat (0.05 $\mathrm{m}^{2}$ and $\sim 5$ to $10 \mathrm{~cm}$ thick) were removed at each sampling period from this very large mat. Each square was collected at a short distance from the previous sample. A plastic plate was carefully inserted underneath the cut section of the mat; the sample was then placed in a plastic container (Tupperware ${ }^{\circledR}$ ). Special care was taken to keep the mats moist with ambient seawater during transportation. The samples were brought back to the laboratory within 1 to $2 \mathrm{~h}$ and stored at in situ temperature. Upon arrival at the laboratory, mat pieces were immediately processed for bioassays.

Pore water nutrient analysis. The piece of mat was cut into $5 \mathrm{~mm}$ slices. Since the mat cores did not contain enough extractable liquid for direct centrifugation, $5 \mathrm{ml}$ of synthetic seawater, free of nitrate or nitrite, was added to each tube, homogenized and centrifuged for $10 \mathrm{~min}$ at $10000 \times g$. Nitrite and nitrate concentrations were analyzed with a Technicon-Auto-Analyser according to Treguer \& Le Corre (1975). Ammonium concentration was determined after $\mathrm{KCl}$ extraction (Laima 1992) using the phenol/hypochlorite method (Koroleff 1969). These values were corrected for dilution and addition of reagent.
Microbial activities. The rate of the different processes associated with the nitrogen cycle (nitrification, denitrification, DNRA and N-fixation and mineralization) were determined in each square of mat. Triplicates were run for each treatment under light $(\sim 550 \mu \mathrm{mol}$ photons $\left.\mathrm{m}^{-2} \mathrm{~s}^{-1}\right)$ and dark incubation conditions.

From each sample of mat, $1 \mathrm{~cm}^{2}$ subsamples $(5 \mathrm{~mm}$ thickness) were placed, with mat surfaces facing up, into a $22 \mathrm{ml}$ headspace vial (HSS 8650, Dany) containing $2 \mathrm{ml}$ of sterile, filtered $(<0.8 \mu \mathrm{m})$ seawater from the sampling site. Measurements were also performed on the surrounding water, with $70 \mathrm{ml}$ of water being incubated in a $100 \mathrm{ml}$ serum flask. The vials were sealed with a rubber stopper. All processes were measured under ambient oxygen levels without nitrogen bubbling. At the beginning of the incubation period, samples were gently agitated by hand once in order to minimize the formation of diffusion gradients just after substrate amendment. The kinetics of the different processes were observed over a period of $10 \mathrm{~h}$ in an incubation chamber maintained at in situ water temperature. Depending on the type of activities measured, the rates of substrate consumption or product accumulation were calculated from the changes in concentration, measured in triplicates, at each sampling time $(0,1,3,5,7$ and $10 \mathrm{~h})$. The concentration was then plotted against time and fitted to the linear model $\left[A(t)=A_{0} \pm m \times t\right)$ using the least squares method, where $t$ is the incubation time, $A_{0}$ is the concentration at $t=0$ and $m$ is the slope of the linear curve. The rates were calculated from the initial linear slope of the curve. Rate uncertainties were calculated from the errors in the linear regressions. A Student's $t$-test was performed on the dataset to evaluate the differences between rates.

Denitrification: Denitrification rates were simultaneously measured using 2 methods: the acetylene inhibition technique (AIT) and the isotope pairing technique (IPM). AIT involves inhibition by acetylene of the last step (nitrous oxide reduction) of denitrification. In this condition, the denitrifying activity corresponds to the kinetics of nitrous oxide accumulation after nitrate reduction. The acetylene concentration in each vial was adjusted to $20 \mathrm{kPa}$ at the beginning of incubation. At the end of each incubation period, the kinetics were stopped by addition of $\mathrm{HgCl}_{2}$ (final concentration $10 \mathrm{mM}$ ) and frozen (Bonin et al. 1998). Nitrous oxide was directly measured in the incubation flask. Dissolved $\mathrm{N}_{2} \mathrm{O}$ was extracted from the liquid bulk using a headspace sampler (HSS 8650, Dany), by automatically shaking of the flask in the oven at $70^{\circ} \mathrm{C}$ for $4 \mathrm{~min}$. The headspace gases were analyzed using an HP 5890 gas chromatograph equipped with a Porapak Q column, and an electron capture detector, with nitrogen as the carrier gas; the temperatures of column, injector 
and detector were set at 80,180 and $250^{\circ} \mathrm{C}$, respectively (Bonin et al. 1998).

The second method (IPM) involves the use of nitrogen stable isotope $\left({ }^{15} \mathrm{NO}_{3}{ }^{-}\right)$and the detection of production of single-labeled $\left({ }^{14} \mathrm{~N}^{15} \mathrm{~N}\right)$ and double-labeled $\left({ }^{15} \mathrm{~N}^{15} \mathrm{~N}\right)$ di-nitrogen by a mass spectrometer (Anagaz 100, MKS) (Nielsen 1992). At the beginning of the experiment, ${ }^{15} \mathrm{NO}_{3}^{-}$(97.4 atom\%, Isotec Mathesson) was added to each vial in order to obtain a final concentration of around $50 \mu \mathrm{M}$. For each point in the kinetic process, $\mathrm{HgCl}_{2}$ (final concentration $10 \mathrm{mM}$ ) was added in order to block the activities, and the incubation flasks were frozen until analysis. After thawing and homogenization, gasses were directly sampled from the vial and injected into the mass spectrometer. Samples were analyzed for ${ }^{28} \mathrm{~N}_{2},{ }^{29} \mathrm{~N}_{2}$ and ${ }^{30} \mathrm{~N}_{2}$. Rates of $D_{15}$ (denitrification of added ${ }^{15} \mathrm{NO}_{3}{ }^{-}$), $D_{14}$ (denitrification of ambient ${ }^{14} \mathrm{NO}_{3}{ }^{-}$), $D_{\mathrm{w}}$ (denitrification of nitrate diffusing from the water column) and $D_{\mathrm{n}}$ (denitrification of nitrate generated by nitrification) were calculated from the initial linear rates of ${ }^{28} \mathrm{~N}_{2},{ }^{29} \mathrm{~N}_{2}$ and ${ }^{30} \mathrm{~N}_{2}$ production and according to the equations derived by Nielsen (1992).

DNRA: Rates were estimated by adding ${ }^{15} \mathrm{NO}_{3}{ }^{-}$ (97.4 atom\%, Isotec Mathesson) to an incubation flask; the amount of ${ }^{15} \mathrm{NO}_{3}{ }^{-}$added was $<10 \%$ of the in situ nitrate concentration. Because of the high ammonium concentration in the mat (millimolar range, see Table 1), addition of $\mathrm{NH}_{4}{ }^{+}$was not necessary in order to inhibit nitrate assimilation. The progressive increase in isotopic enrichment of ammonium was monitored over time as the substrate (nitrate) was used. Immediately after incubation, $1 \mathrm{ml}$ of surrounding water was sampled, transferred to a $50 \mathrm{ml}$ screwed flask, and ammonium was extracted from the solution by microdiffusion at $60^{\circ} \mathrm{C}$ (Brooks et al. 1989). The samples were treated with a mid-alkali (MgO) to convert $\mathrm{NH}_{4}{ }^{+}$to $\mathrm{NH}_{3}$, which was trapped on acidified $\left(50 \mu \mathrm{l}, 0.5 \mathrm{~N} \mathrm{H}_{2} \mathrm{SO}_{4}\right)$, precombusted Whatman GF/C filters and analyzed for ${ }^{15} \mathrm{~N}$ content by mass spectrometry (Tracer Mass, European Scientific) (Bonin 1996). The rates of dissimilatory ammonium production were calculated as previously described (Bonin et al. 1998).

Nitrification: The net nitrification not coupled to denitrification can be measured by monitoring the isotope dilution of added ${ }^{15} \mathrm{NO}_{3}{ }^{-}$(Koike \& Hattori 1978, Nishio et al. 1983). This activity was measured in the same flasks as those used for the determination of DNRA activities. After 2 successive extractions of ${ }^{14,15} \mathrm{NH}_{4}{ }^{+}$by microdiffusion, the remaining ${ }^{15} \mathrm{NO}_{3}{ }^{-}$in the flask was reduced chemically to ammonium with Devarda's alloy and subsequently microdiffused (Brooks et al. 1989). The rate of nitrification was calculated from isotopic dilution of co-diffused nitrate and nitrite according to the equation developed by Glibert et al. (1982).
Ammonium produced by mineralization: The rate of mineralization was measured along with the isotopic dilution of ${ }^{15} \mathrm{NH}_{4}{ }^{+}$amongst ${ }^{14} \mathrm{NH}_{4}{ }^{+}$in the mat and in the overlying water. Conditions were identical to those used for the measurement of nitrification activity.

Di-nitrogen fixation: $\mathrm{N}$-fixation rates were measured in the microbial mat by acetylene reduction assays following the procedure of Bebout et al. (1987): $2 \mathrm{ml}$ of the headspace gas was replaced by acetylene in the rubber-stopper-sealed flasks containing the microbial mat, as previously described. The ethylene concentration was measured using a mass spectrometer (Anagaz $100 \mathrm{MKS}$ ) by monitoring the signal at $\mathrm{m} / \mathrm{z}=$ 27 and by taking into account the cracking pattern to avoid Mass 28, where the ethylene peak would have been masked by $\mathrm{N}_{2}(\mathrm{~m} / \mathrm{z}=28)$ (Lloyd \& Scott 1983). Considering the salinity and the ratio of liquid/gas phases in the incubation flask, we assumed that the amount of soluble ethylene was negligible. Ethylene production rates were transformed to $\mathrm{N}_{2}$-production rates using a theoretical conversion factor of 3 found applicable to the mat communities $\left(3 \mathrm{C}_{2} \mathrm{H}_{4}\right.$ per $\mathrm{N}_{2}$ ) (Hardy et al. 1968, Joye \& Paerl 1994).

\section{RESULTS}

\section{Ammonium and nitrate pools in the Camargue mat}

Average concentrations of nitrate, nitrite and ammonium were measured in the upper $0.5 \mathrm{~cm}$ of the mat and in the overlying water (Table 1). In the water, the nitrate and ammonium concentrations ranged from 2.1 to $5.8 \mu \mathrm{M}$ and from 18.2 to $51.1 \mu \mathrm{M}$, respectively. The highest nitrate concentrations were observed during colder months (January and March). In the microbial mat, nitrate pools were markedly lower than the total (dissolved plus exchangeable) ammonium pool. The nitrate concentrations in the mat were in the same

Table 1. Average concentrations of nitrate and ammonium in the top $0.5 \mathrm{~cm}$ of the microbial mat and in the overlying water of the Camargue. Note change of scale in ammonium concentration in the mat

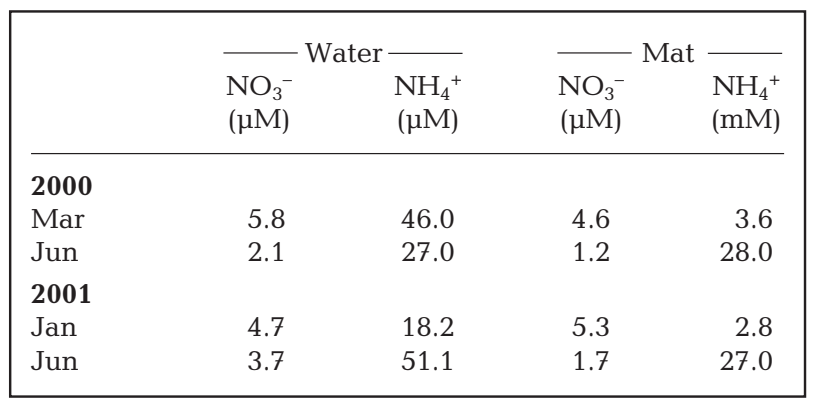


range as those found in the overlying water, and their seasonal variations showed the same tendency. Within the mat, ammonium concentrations were very high, with highest values (27 to $28 \mathrm{mM}$ ) observed in both June samples, while the concentrations were about 10 times lower in the colder months.

\section{Bacterial activities}

Denitrification rates were measured simultaneously using both AIT and IPM methods. Results obtained using AIT are reported in Fig. 2. Under our natural incubation conditions, without nitrate or carbon amendment, the linear nitrous oxide accumulation increased only during the first hour. The denitrifying rates were very low and ranged from 0 to $0.24 \pm$ $0.06 \mathrm{mmol} \mathrm{N}_{2} \mathrm{O} \mathrm{m}^{-2} \mathrm{~d}^{-1}$. In most cases, under light incubation, denitrification was below the detection limit of this method and only detectable in winter 2001. When samples were incubated in the dark, denitrification showed seasonal variation, with higher rates in March 2000.

Denitrifying activities were also determined by IPM. Reduction of ${ }^{14} \mathrm{NO}_{3}{ }^{-}$and ${ }^{15} \mathrm{NO}_{3}{ }^{-}$in the mat samples resulted in the formation of the single- and doublelabeled isotopes $\left({ }^{14} \mathrm{~N}^{14} \mathrm{~N},{ }^{14} \mathrm{~N}^{15} \mathrm{~N}\right.$ and $\left.{ }^{15} \mathrm{~N}^{15} \mathrm{~N}\right)$. According to the stoichiometry of denitrification, added ${ }^{15} \mathrm{NO}_{3}^{-}$combines with indigenous ${ }^{14} \mathrm{NO}_{3}{ }^{-}$originating either from nitrification or from the overlying water. The total denitrification $\left(D_{\mathrm{w}}+D_{\mathrm{n}}\right)$ activities (Fig. 3) ranged from $0.65 \pm 0.05$ to $2.74 \pm 0.30 \mathrm{mmol} \mathrm{m}^{-2} \mathrm{~d}^{-1}$ under light conditions and from $0.85 \pm 0.08$ to $2.74 \pm$ $0.46 \mathrm{mmol} \mathrm{m}^{-2} \mathrm{~d}^{-1}$ under dark conditions (Fig. 3). Denitrifying activities measured in March and June were about 4 -fold higher than those determined in winter. In January, $D_{\mathrm{n}}$ was below the detection limit, and it reached $0.89 \pm 0.10 \mathrm{mmol} \mathrm{m}^{-2} \mathrm{~d}^{-1}$ in June 2000. Denitrification rates of nitrate originating from the overlying water were generally higher and fluctuated from

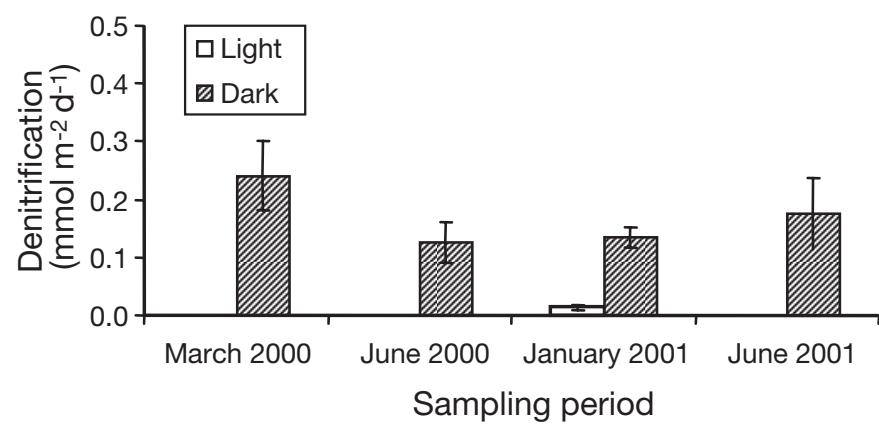

Fig. 2. Natural denitrification rates $( \pm \mathrm{SE})$ of mat sample measured with the acetylene blocking method (AIT) under light (white bar) and dark (shaded bars) conditions during 4 sampling periods
$0.65 \pm 0.05$ to $2.20 \pm 0.37 \mathrm{mmol} \mathrm{m}^{-2} \mathrm{~d}^{-1}$ from January to June 2001, respectively. No significant effect of light conditions was observed on the denitrification rates.

Nitrification rates were also determined for the same periods (Fig. 4). In March and June nitrification rates were around $1 \mathrm{mmol} \mathrm{m}^{-2} \mathrm{~d}^{-1}$, the lowest rates being measured in winter. No significant effect of light conditions was observed on the nitrification rates.

$\mathrm{N}$-fixation also displayed a clear seasonal pattern (Fig. 5), with the highest values observed in June and

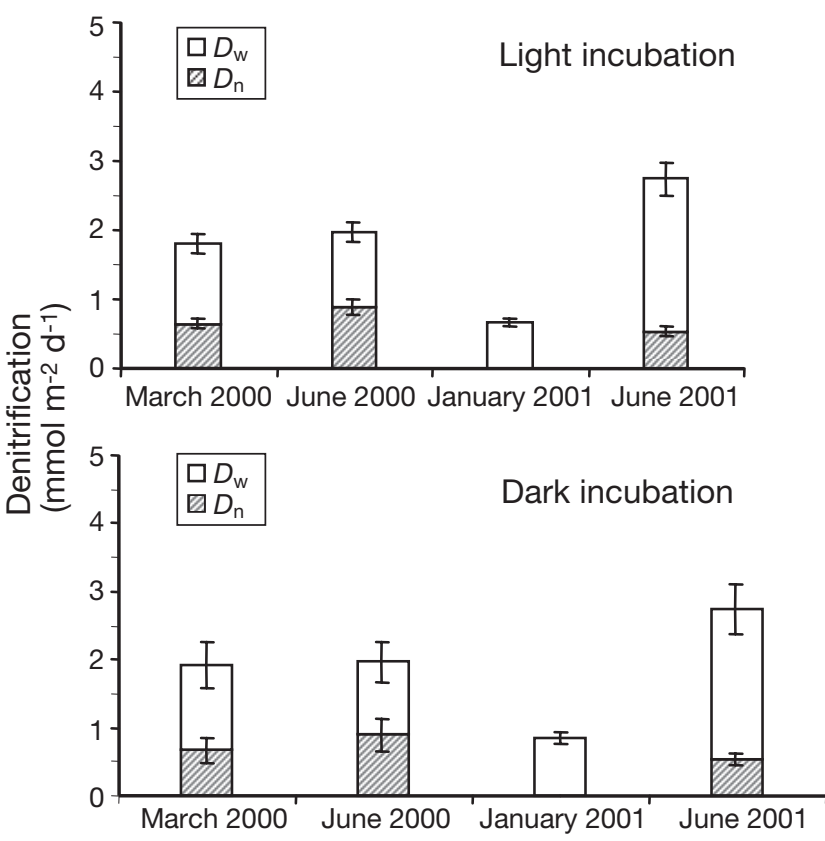

Fig. 3. Natural denitrification rates $( \pm \mathrm{SE})$ of mat samples measured with the isotope pairing method (IPM) with ${ }^{15} \mathrm{NO}_{3}$ under light and dark incubation conditions. White bars correspond to denitrified nitrate from the water column $\left(D_{\mathrm{w}}\right)$; shaded bars correspond to denitrified nitrate from the reduction of ammonium by nitrifiers $\left(D_{\mathrm{n}}\right)$

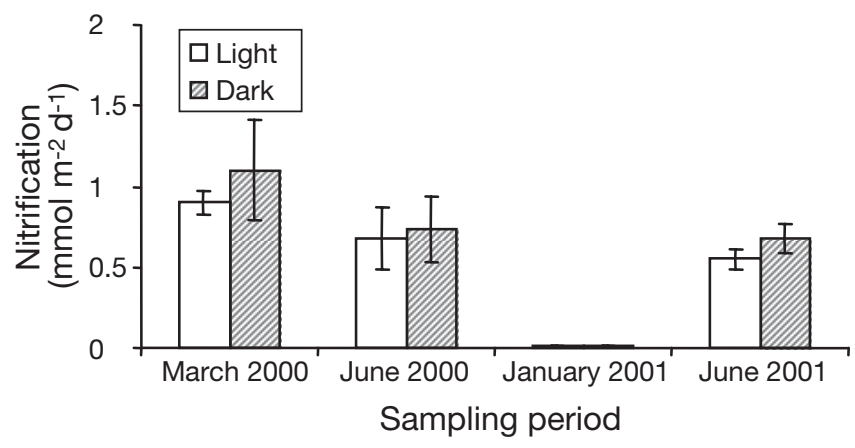

Fig. 4. Net nitrification rates $( \pm \mathrm{SE})$ of mat sample incubated under dark (shaded bars) or light (white bars) conditions. Nitrification rates were calculated from isotopic dilution of nitrate and the nitrite pool according to the equation developed by Glibert et al. (1982) 


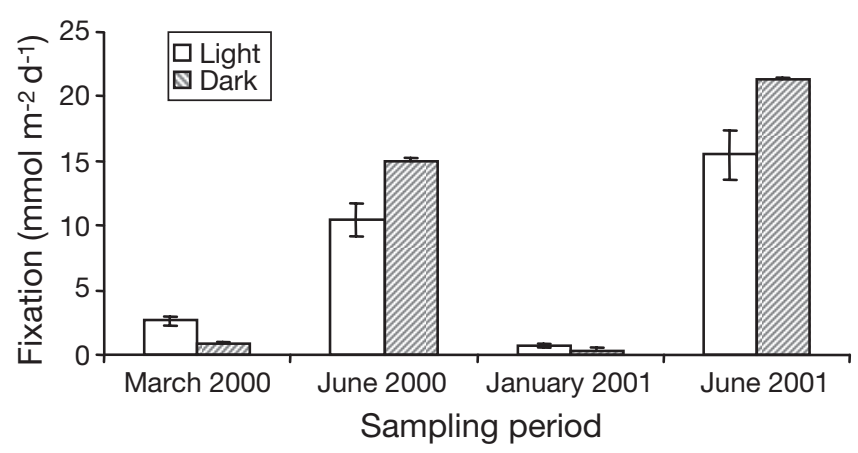

Fig. 5. N-fixation rates $( \pm \mathrm{SE})$ of mat samples incubated under dark (shaded bars) or light conditions (white bars). N-fixation rates were measured in the microbial mats by acetylene reduction assays following the procedure of Bebout et al. (1987)

the lowest in January. The maximum activity (21.26 \pm $0.25 \mathrm{mmol} \mathrm{m}^{-2} \mathrm{~d}^{-1}$ ) was observed under dark incubation conditions in June 2001. In June of both years, mat samples incubated in the dark exhibited $\mathrm{N}$-fixation rates significantly higher than those incubated in the light - in contrast to January and March samples.

\section{Nitrogen budget}

Activities of the complete nitrogen cycle (dissimilative and assimilative processes, with the exception of anammox) and the nitrogen budget were calculated in the mat and in the overlying water. Results are illustrated in Fig. 6. The values reported for the different activities in June are the means of 2000 and 2001. All activities measured in January were much lower than those measured in June. Whatever the sampling period, the rates of mineralization within the mat were very high (up to $410 \mu \mathrm{mol} \mathrm{l}^{-1} \mathrm{~h}^{-1}$ ) and led to a strong production of ammonium. Light exposure has no effect on mineralization rates in June, whereas an effect was observed in January (Fig. 6). The nitrifying activities measured in the mat and in the overlying water were in the same range. A coupling between the processes of nitrification and denitrification of the nitrate produced from nitrification $\left(D_{\mathrm{n}}\right)$ was observed in June and January. In January, when the nitrification rate was the lowest $\left(0.05 \mu \mathrm{mol} \mathrm{l}^{-1} \mathrm{~h}^{-1}\right)$, most of the denitrified nitrate came from the water column, $\left(D_{\mathrm{w}}\right)$. In June about $1 / 3$ of the total denitrification $\left(D_{\mathrm{n}}+D_{\mathrm{w}}=16.4 \mu \mathrm{mol} \mathrm{l^{-1 }} \mathrm{h}^{-1}\right)$ was coupled with nitrification $\left(5.9 \mu \mathrm{mol} \mathrm{l}^{-1} \mathrm{~h}^{-1}\right.$ for $\left.D_{\mathrm{n}}\right)$. In the overlying water, the denitrification rates were lower than the detection limit. The DNRA was only detectable in June, and this process appeared to make a minor contribution to the nitrogen cycle of this microbial mat.

The net balance between $\mathrm{N}$-fixation and denitrification (N-fixation minus $\mathrm{N}$-denitrified), which represents the net flux of combined nitrogen, displayed seasonal variability (Fig. 7). In January, the net nitrogen fluxes were weak and the nitrogen loss via denitrification slightly exceeded the fixed nitrogen. In contrast, in June, the nitrogen fluxes were positive and only 13 and $18 \%$ of the new nitrogen input by $\mathrm{N}$-fixation were subsequently lost by microbial denitrification during dark and light incubations, respectively.

\section{DISCUSSION}

Here, we report on the first comprehensive examination of the nitrogen cycle within a mat and in the surrounding water. In preliminary tests, anammox seemed negligible in this mat, whereas in recent publications it seemed more widely spread in sediments than has previously been thought (Dalsgaard et al. 2005). Risgaard-Petersen et al. (2005) studied the effect of microphytobenthos on denitrification and anammox in sediments. These authors demonstrated that the anammox process is not ubiquitous in sediments colonized by microphytobenthos. They suggested that anammox is of very limited significance in environments that periodically experience $\mathrm{N}$-limitation and that the occurrence of high rates of anammox in coastal sediments is limited to estuaries with permanently high concentrations of $\mathrm{NO}_{3}^{-}$in the water column. Anammox was not, therefore, investigated in the present study.

Microbial-mediated nitrogen transformations were examined under dark and light incubation conditions in different seasons in the first $5 \mathrm{~mm}$ of the mat. In this zone, the depth penetration of oxygen varied according to daily photosynthetic activity and never exceeded $1.5 \mathrm{~mm}$ (Wieland et al. 2005), much shallower than generally found in sediments (Meyer et al. 2001). In our study, we have shown that a complex nitrogen cycle was present in the microbial mat of the Camargue, which can act as a source or sink of nitrogen depending on the season. Mats were inhabited by productive microbial communities and served as net sources of combined nitrogen, since $\mathrm{N}$-fixation rates exceeded denitrification rates throughout most of the year. However, during winter, a different pattern was observed, with denitrification rates exceeding $\mathrm{N}$ fixation rates. During daytime in winter the mat, therefore, acts as a sink for nitrogen.

In the literature, the main processes of the nitrogen cycle have often been studied separately. The aim of the present study was to measure them simultaneously from the same sample. $\mathrm{N}$-fixation rates have commonly been reported in the literature, and the high $\mathrm{N}$-fixation rates described in our study were in the same range as those reported for other microbial mats (Joye \& Paerl 

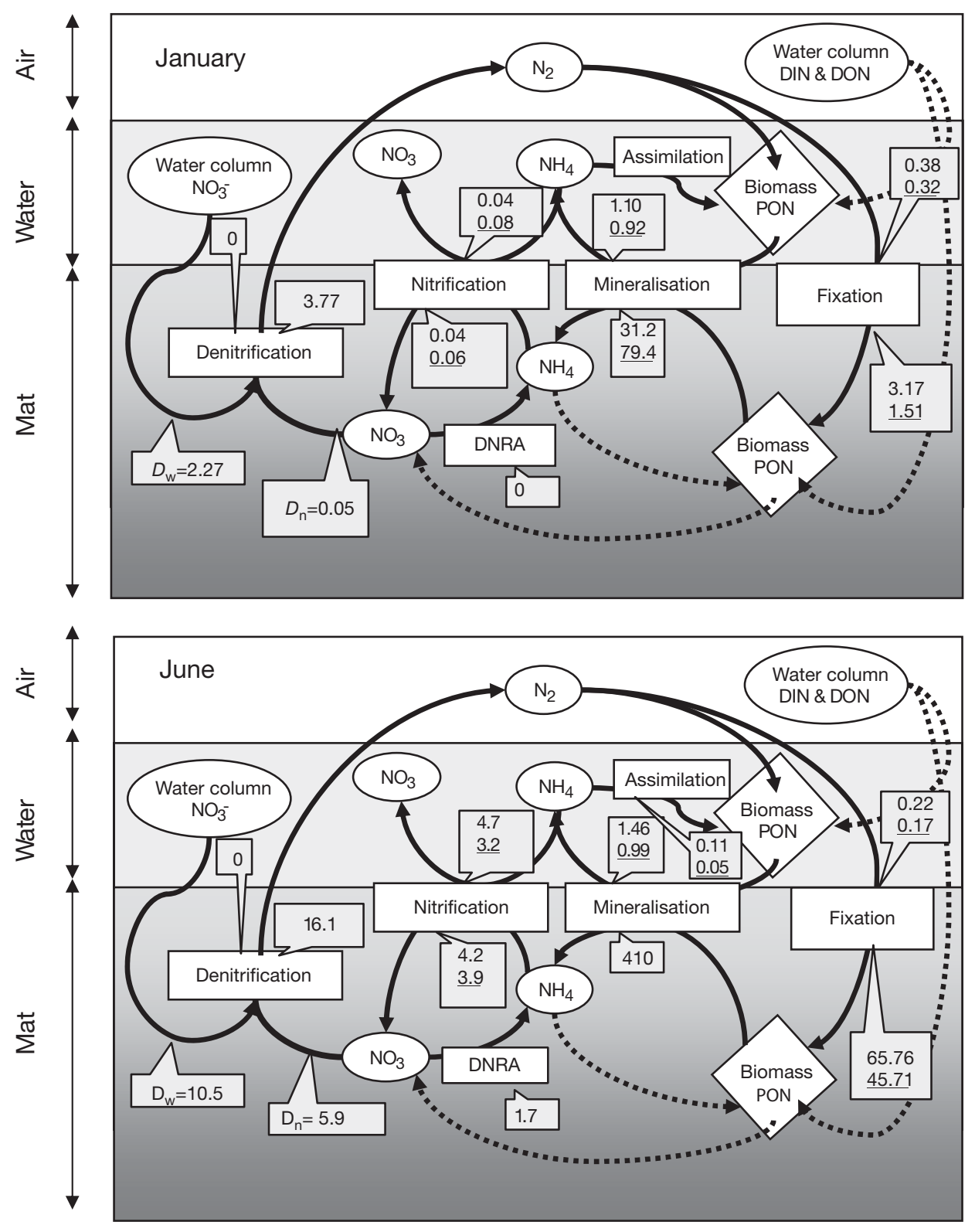

Fig. 6. Activities of the main processes (dissimilative and assimilative) of the nitrogen cycle in the mat and in the overlying water for June 2000 and January 2001. Measurements were performed in darkness or light. Activities are expressed in $\mu \mathrm{mol} \mathrm{l}^{-1} \mathrm{~h}^{-1}$. The underlined rates correspond to light incubation. When no effect of light was observed, only 1 value is noted (DIN: dissolved inorganic nitrogen; DON: dissolved organic nitrogen; PON: particulate organic nitrogen; DNRA: dissimilative nitrate reduction to ammonium)

1994, Currin et al. 1996, Currin \& Paerl 1998, Golet \& Ward 2001). Experiments consisting of ambient light and dark treatments were designed to determine the diel pattern of N-fixation. Significantly higher fixation rates were noted in summer during dark incubations, whereas higher fixation rates were observed during light incubations in the cold period. The same seasonal $\mathrm{N}$-fixation dynamics have been reported in other marine microbial mats (Paerl et al. 1996). The diel cycle of $\mathrm{N}_{2}$ fixation reflects energy sources and demands, as well as environmental constraints or the cell metabolism of the nitrogen fixers within the mat. Several articles have been published on the ecology and biogeochemistry of cyanobacteria-dominated microbial mats (Pinckney et al. 1995, Paerl et al. 1996). Nitrogenase, which catalyzes the reduction of di-nitrogen to ammonium, is rapidly inactivated by oxygen. Oxygenic photoautotrophs, which fix nitrogen, must 


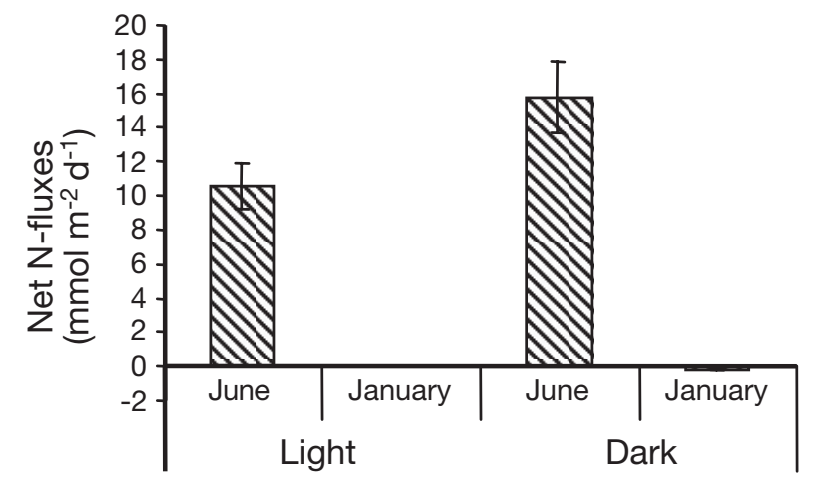

Fig. 7. Net balance $( \pm \mathrm{SE})$ between $\mathrm{N}$-fixation and denitrification ( $\mathrm{N}$-fixation minus $\mathrm{N}$-denitrified, expressed in $\mathrm{mmol} \mathrm{m} \mathrm{m}^{-2} \mathrm{~d}^{-1}$ )

protect nitrogenase from oxygen produced during photosynthesis. Heterocysteous cyanobacteria are capable of daytime $\mathrm{N}$-fixation by spatially separating oxygenic photosynthesis and nitrogenase activities. These strains presented high daytime and low nighttime fixation rates, whereas non-heterocysteous cyanobacteria exhibited low daytime $\mathrm{N}_{2}$ fixation rates. Fourçans et al. (2004) have shown that in summer (June 2001) this mat was composed of several groups of organisms in which diazotrophs could be found, i.e. cyanobacteria belonging to the Lyngbya, Limnothhrix, Microcoleus, Phormidium and Synechocystis groups and purple non-sulfur bacteria morphologically resembling the Rhodospirilaceae and Chromatiaceae families, but also sulfate-reducing bacteria of the Desulfobacter-like Desulfovibrio and Desulfonema-like species. Potential $\mathrm{N}_{2}$ fixers can be found in most of the genera described in this mat. In all cases, it is difficult to ascertain which of the many taxa composing this microbial mat are involved in this process. In the literature, it has been shown that Microcoleus chthonoplastes lacks the nif $\mathrm{H}$ gene and that $\mathrm{N}$-fixation in the Microcoleus-dominated mat is often attributable to heterotrophic bacteria (Omoregie et al. 2004a, Steppe \& Paerl 2005). Seasonal changes in bacterial diazotrophic community composition might have played a crucial role in determining the diel rates and seasonal patterns of $\mathrm{N}_{2}$ fixation. $\mathrm{N}$-fixation rates (Joye \& Paerl 1994, Currin et al. 1996, Currin \& Paerl 1998, Golet \& Ward 2001) and studies on the diazotrophic community structure using sequences of the nif $\mathrm{H}$ fragment have commonly been reported in the literature (Steppe et al. 1996, 2001, Omoregie et al. 2004a,b, Steppe \& Paerl 2005), but information regarding the ultimate fate of microbially fixed nitrogen in mat is lacking. However, whether the mat acts as a source or sink for combined $\mathrm{N}$ depends not only on the balance between $\mathrm{N}$-fixation and denitrification but also on the rate of mineralization and on the ability of the organisms to assimilate nitrogen as ammonium. Regeneration processes occurring within the mat transform organically bound nitrogen to its biologically available form (mineralization). This regenerated nitrogen has several potential fates: it may (1) diffuse towards the overlying water, resulting in a loss for the mat; (2) be assimilated in the mat and thus retain nitrogen in the system; or (3) be nitrified then denitrified, resulting in a net loss of nitrogen for the mat but also for the coastal ecosystem.

Lowest nitrification rates were observed during light incubation. This phenomenon has already been described by several authors for other ecosystems. Different reasons were evoked, including unfavorable competition with microalgae for ammonium (RisgaardPetersen 2003), excess partial pressure of oxygen (Rysgaard et al. 1994), low $\mathrm{CO}_{2}$ concentration, or high light intensity. The enzyme responsible for the first step of nitrification (ammonium mono-oxygenase) is inhibited by wavelengths <480 nm (Guerrero \& Jones 1996). From measured spectral scalar irradiance profiles, it has been reported that scalar irradiance measured at around $480 \mathrm{~nm}$ corresponded to about $50 \%$ of the incident irradiance in the upper $0.5 \mathrm{~cm}$ of the mat (Fourçans et al. 2004).

In the present study, denitrification rates were measured simultaneously by AIT and IPM. The measurements by AIT allowed us to compare the denitrification rates in this mat with those from previous studies. This method was easy and fast, but several well-known biases must be taken into account, which is why the AIT rates were also measured by IPM. The denitrifying rates measured by AIT were very low, undetectable in most cases and always lower than those measured by IPM. These results were in good agreement with those reported by several authors who found, using AIT, potential denitrifying activity only after nitrate amendment. They concluded that nitrate was the limiting factor for the expression of denitrification in microbial mats. Low denitrifying rates were only measurable during the first hour of incubation. Continued incubation of amended mat systems resulted in the decrease of denitrification rates, suggesting complete nitrate consumption during the first hour of incubation or the consumption of nitrous oxide despite the presence of acetylene. Incomplete acetylene blockage, leading to underestimation of denitrification, has frequently been reported in the presence of sulfide and low nitrate concentrations (Tam \& Knowles 1979, Slater \& Capone 1989), and these conditions have often been encountered in microbial mats. Nitrification can be a considerable source of nitrate in this microbial mat. As acetylene also inhibits nitrification (Hynes \& Knowles 1978), AIT does not allow the detection of denitrifying activities coupled with nitrification. During our study, seasonal variations in nitrification rates occurred, leading to variations in the 
source of nitrate consumed by denitrifiers. Since nitrification was one of the nitrate sources in spring and summer, a rapid exhaustion of the nitrate pore water pool led to underestimation of the true denitrification rate, due to the co-inhibition of nitrification by acetylene (Hynes \& Knowles 1978). The present results are in agreement with those reported by Lohse et al. (1996), and suggest that previous data, obtained by AIT, severely underestimated denitrification rates in sediments. However, IPM also presents limitations, as this method is based on a number of assumptions, including the existence of a constant ratio ${ }^{14} \mathrm{NO}_{3}:{ }^{15} \mathrm{NO}_{3}$. This ratio can be constant only if these 2 isotopes are mixed in a homogeneous way and if diffusion of both nitrate isotopes is identical. The fact that the 2 nitrate isotopes diffuse in a similar way is generally admitted. However, this assumption has been subject to controversy for certain types of sediments (Middelburg et al. 1996a,b, Nielsen et al. 1996). Middelburg's approach is only interesting if one wishes to look at total denitrification rates, which was not the aim of the present study, where the sources of denitrified nitrate were to be identified. In January, during the cold period, nitrate originating from overlying water was the only source of nitrate for denitrification $\left(D_{\mathrm{w}}\right)$, whereas the coupled rate $\left(D_{\mathrm{n}}\right)$ was more important during spring and summer. During these seasons, about 25 to $50 \%$ of the nitrate produced in situ by nitrification was directly denitrified, leading to a loss of nitrogen in the ecosystem. The switch from internal (nitrification) to external (creek water) nitrate sources reflected the ability of the mat denitrifiers to impact the nitrogen cycle on different spatial scales. We suspect that the in situ spatial distribution and the rates of the processes associated with the nitrogen cycle in the microbial mats possibly varied rapidly in response to the shifts in environmental conditions that may have occurred during the diel cycle of photosynthesis.

Moreover, no significant effect of light conditions was observed on the denitrification rates determined by IPM, whereas lower denitrification rates were observed with light incubation by AIT. The same inhibitory effect of light on denitrification rates was also observed by Currin et al. (1996) using AIT. This can be attributed to the effect of oxygenic phototrophs on pore water oxygen and dissolved inorganic nitrogen concentration (Rysgaard et al. 1994). During light incubation, the increase of nitrate uptake by phototrophs (which would limit the amount of nitrate available for denitrifiers) could be strongly involved in the dynamics between oxygenic photosynthesis, oxygen respiration and denitrification. In the presence of acetylene, when nitrification is blocked, competition for nitrate becomes significant (Risgaard-Petersen 2003). Photosynthetic oxygen production might stimu- late nitrification, leading to a stimulation of coupled nitrification-denitrification compared to the dark situation. Seasonally, maximum denitrification rates were observed during summer, and lower rates were observed during winter. During the winter, low rates of photosynthesis reduced the oxygen inhibition of denitrification, and high water column concentrations of dissolved inorganic nitrogen depressed $\mathrm{N}$-fixation.

In conclusion, the present study has contributed new information on the ecology of the nitrogen cycle in microbial mats of the Camargue, showing domination of the net nitrogen budget by denitrification during winter, whereas, during the productive season, denitrification rates amounted to at most $18 \%$ and on average $12 \%$ of the $\mathrm{N}$-fixation rates.

Acknowledgements. We acknowledge the financial support of the EC (MATBIOPOL project, Grant EVK3-CT-199900010).

\section{LITERATURE CITED}

Bebout B, Paerl HW, Crocker K, Prufer L (1987) Diel interactions of oxygenic photosynthesis and $\mathrm{N}_{2}$ fixation (acetylene reduction) in a marine microbial mat community. Appl Environ Microbiol 53:2353-2362

Bonin P (1996) Anaerobic nitrate reduction to ammonium in two strains isolated from coastal marine sediment: a dissimilatory pathway. FEMS Microbiol Ecol 19:27-38

Bonin P, Omnes P, Chalamet A (1998) Simultaneous occurrence of denitrification and nitrate ammonification in sediments of the French Mediterranean coast. Hydrobiologia 389:169-182

Brooks PD, Stark JM, McInteer BB, Preston T (1989) Diffusion method to prepare soil extracts for automated nitrogen-15 analysis. Soil Sci Soc Am J 53:1707-1711

Caumette P, Matheron R, Raymond N, Relexans JC (1994) Microbial mats in the hypersaline ponds of Mediterranean salterns (Salins-de-Giraud, France). FEMS Microbiol Ecol 13:273-286

Currin CA, Paerl HW (1998) Environmental and physiological controls on diel patterns of $\mathrm{N}-2$ fixation in epiphytic cyanobacterial communities. Microb Ecol 35:34-45

Currin CA, Joye SB, Paerl HW (1996) Diel rates of N-2fixation and denitrification in a transplanted Spartina alterniflora marsh-implications for N-flux dynamics. Estuar Coast Shelf Sci 42:597-616

Dalsgaard T, Thamdrup B, Canfield DE (2005) Anaerobic ammonium oxidation (anammox) in the marine environment. Res Microbiol 156:457-464

Fourçans A, Garcia de Oteyza T, Wieland A, Solé A and 8 others (2004) Characterization of functional bacterial groups in a hypersaline microbial mat community (Salinsde-Giraud, Camargue, France). FEMS Microbiol Ecol 51:55-70

Glibert PM, Lipschultz F, McCarthy JJ, Altabet MA (1982) Isotope-dilution models of uptake and remineralization of ammonium by marine plankton. Limnol Oceanogr 27: $639-650$

Golet DS, Ward BB (2001) Vertical distribution of denitrification potential, denitrifying bacteria, and benzoate utilization in intertidal microbial mat communities. Microb Ecol 42:22-34 
Guerrero MA, Jones RD (1996) Photoinhibition of marine nitrifying bacteria. 1. Wavelength-dependent response. Mar Ecol Prog Ser 141:183-192

Hardy RWF, Holsten M, Jackson RD, Burns EK (1968) The acetylene-ethylene assay for $\mathrm{N}$ fixation: laboratory and field evaluation. Plant Physiol 43:1165-1207

Hyman MR, Wood PM (1985) Suicidal labelling and inactivation of ammonia mono-oxygenase by acetylene. Biochem J 227:717-719

Hynes RK, Knowles R (1978) Inhibition by acetylene of ammonia oxidation in Nitrosomonas europea. FEMS Microbiol Lett 4:319-325

Jørgensen BB, Revsbech NP (1989) Oxygen uptake, bacterial distribution, and carbon-nitrogen-sulfur cycling in sediments from Baltic-North Sea transition. Ophelia 31:51-72

Joye SB, Paerl HW (1994) Nitrogen cycling in microbial mats: rates and patterns of denitrification and nitrogen fixation. Mar Biol 119:285-295

Koike I, Hattori A (1978) Denitrification and ammonia formation in anaerobic coastal sediments. Appl Environ Microbiol 35:278-282

Koroleff F (1969) Direct determination of ammonia in natural water as indophenol blue. Rapp P-V Reun Cons Int Explor Mer 9:1-6

Laima MJC (1992) Extraction and seasonal variation of $\mathrm{NH}_{4}{ }^{+}$ pools in different types of coastal marine sediments. Mar Ecol Prog Ser 82:75-84

Lloyd D, Scott RI (1983) Direct measurement of dissolved gases in microbiological systems using membrane inlet mass spectrometry. J Microbiol Methods 1:313-328

Lohse L, Kloosterhuis HT, Raaphorst WV, Helder W (1996) Denitrification rates as measured by the isotope pairing method and by the acetylene inhibition technique in continental shelf sediments of the North Sea. Mar Ecol Prog Ser 132:1-3

Meyer RL, Kjaer T, Revsbech NP (2001) Use of NO $\mathrm{X}_{\text {microsen- }}$ sors to estimate the activity of sediment nitrification and $\mathrm{NO}_{\mathrm{X}}$ consumption along an estuarine salinity, nitrate, and light gradient. Aquat Microb Ecol 26:181-193

Middelburg JJ, Soetaert K, Herman PMJ (1996a) Evaluation of the nitrogen isotope-pairing method for measuring benthic denitrification: a simulation analysis. Limnol Oceanogr 41:1839-1844

Middelburg JJ, Soetaert K, Herman PMJ (1996b) Evaluation of the nitrogen isotope-pairing method for measuring benthic denitrification: a simulation analysis-Comment. Limnol Oceanogr 41:1846-1847

Nielsen LP (1992) Denitrification in sediment determined from nitrogen isotope pairing. FEMS Microbiol Ecol 86: 357-362

Nielsen LP, Risgaard-Petersen N, Rysgaard S, Blackburn TH (1996) Evaluation of the nitrogen isotope-pairing method for measuring benthic denitrification: a simulation analysis - Reply. Limnol Oceanogr 41:1845-1846

Nishio T, Koike I, Hattori A (1983) Estimates of denitrification and nitrification in coastal and estuarine sediments. Appl Environ Microbiol 45:444-450

Omoregie EO, Crumbliss LL, Bebout BM, Zehr JP (2004a) Comparison of diazotroph community structure in Lyng-

Editorial responsibility: Otto Kinne (Editor-in-Chief), Oldendorf/Luhe, Germany bya sp. and Microcoleus chthonoplastes dominated microbial mats from Guerrero Negro, Baja, Mexico. FEMS Microbiol Ecol 47:305-318

Omoregie EO, Crumbliss LL, Bebout BM, Zehr JP (2004b) Determination of nitrogen-fixing phylotypes in Lyngbya sp. and Microcoleus chthonoplastes cyanobacterial mats from Guerrero Negro, Baja California, Mexico. Appl Environ Microbiol 70:2119-2128

Paerl HW, Pinckney JL (1996) A mini-review of microbial consortia: their roles in aquatic production and biogeochemical cycling. Microb Ecol 31:225-247

Paerl HW, Joye SB, Fritzpatrick M (1993) Evaluation of nutrient limitation of $\mathrm{CO}_{2}$ and $\mathrm{N}_{2}$ fixation in marine microbial mats. Mar Ecol Prog Ser 101:297-306

Paerl HW, Fritzpatrick M, Bebout B (1996) Seasonal nitrogen fixation dynamics in a marine microbial mat: potential roles of cyanobacteria and microheterotrophs. Limnol Oceanogr 41:419-427

Pinckney JL, Paerl HW, Fritzpatrick M (1995) Impacts of seasonality and nutrients on microbial mat community structure and function. Mar Ecol Prog Ser 123:207-216

Risgaard-Petersen N (2003) Coupled nitrification-denitrification in autotrophic and heterotrophic estuarine sediments: on the influence of benthic microalgae. Limnol Oceanogr 48:93-105

Risgaard-Petersen N, Meyer RL, Revsbech NP (2005) Denitrification and anaerobic ammonium oxidation in sediments: effects of microphytobenthos and $\mathrm{NO}_{3}{ }^{-}$. Aquat Microb Ecol 40:67-76

Rysgaard S, Risgaard-Petersen N, Nielsen LP, Revsbech NP (1994) Oxygen regulation of nitrification and denitrification in sediments. Limnol Oceanogr 39:1643-1652

Slater JM, Capone DG (1989) Nitrate requirement for acetylene inhibition of nitrous oxide reduction in marine sediments. Microb Ecol 17:143-157

Steppe TF, Paerl HW (2005) Nitrogenase activity and nifH expression in a marine intertidal microbial mat. Microb Ecol 49:315-324

Steppe TF, Olson JB, Paerl HW, Litaker RW, Belnap J (1996) Consortial N-2 fixation: a strategy for meeting nitrogen requirements of marine and terrestrial cyanobacterial mats. FEMS Microbiol Ecol 21:149-156

Steppe TF, Pinckney JL, Dyble J, Paerl HW (2001) Diazotrophy in modern marine Bahamian stromatolites. Microb Ecol 41:36-44

Tam TY, Knowles R (1979) Effect of sulfide and acetylene on nitrous oxide reduction by soil and Pseudomonas aeruginosa. Can J Microbiol 25:1133-1138

Treguer P, Lecorre P (1975) Manuel d'analyse des sels nutritifs dans l'eau de mer. Laboratoire d'Océanographie Chimique, Université de Bretagne Occidentale, Brest

Van Raalte CD, Patriquin DG (1979) Use of the 'acetylene blockage' technique for assaying denitrification in a salt marsh. Mar Biol 52:315-326

Walter HM, Keeney DR, Fillery IR (1979) Inhibition of nitrification by acetylene. Soil Sci Soc Am J 43:195-201

Wieland A, Zopfi J, Benthien M, Kuhl M (2005) Biogeochemistry of an iron-rich hypersaline microbial mat (Camargue, France). Microb Ecol 49:34-49

Submitted: April 1, 2005; Accepted: January 31, 2006

Proofs received from author(s): August 14, 2006 